\title{
Colonized Sabethes cyaneus, a Sylvatic New World Mosquito Species, Shows a Low Vector Competence for Zika Virus Relative to Aedes aegypti
}

\author{
Ajit K. Karna ${ }^{1}$ (D), Sasha R. Azar ${ }^{2,4,6}$, Jessica A. Plante ${ }^{2}$, Rumei Yun ${ }^{2,4}$, Nikos Vasilakis ${ }^{3,4,5,6,7}$, \\ Scott C. Weaver ${ }^{2,3,4,5,6,7}$, Immo A. Hansen ${ }^{1}$ and Kathryn A. Hanley ${ }^{1, *}$ \\ 1 Department of Biology, New Mexico State University, Las Cruces, NM 88003, USA; \\ akarna@nmsu.edu (A.K.K.); immoh@nmsu.edu (I.A.H.) \\ 2 Department of Microbiology and Immunology, University of Texas Medical Branch, Galveston, TX 77555, \\ USA; srazar@utmb.edu (S.R.A.); japlante@utmb.edu (J.A.P.); ruyun@utmb.edu (R.Y.); \\ sweaver@utmb.edu (S.C.W.) \\ 3 Department of Pathology, University of Texas Medical Branch, Galveston, TX 77555, USA; \\ nivasila@utmb.edu \\ 4 Institute for Human Infections and Immunity, University of Texas Medical Branch, Galveston, \\ TX 77555, USA \\ 5 Center for Biodefense and Emerging Infectious Diseases, University of Texas Medical Branch, Galveston, \\ TX 77555, USA \\ 6 Institute for Translational Sciences, University of Texas Medical Branch, Galveston, TX 77555, USA \\ 7 Center for Tropical Diseases, University of Texas Medical Branch, Galveston, TX 77555, USA \\ * Correspondence: khanley@nmsu.edu; Tel.: +1-575-646-4583
}

Received: 12 July 2018; Accepted: 14 August 2018; Published: 16 August 2018

\begin{abstract}
The introduction of Zika virus (ZIKV) to the Americas raised concern that the virus would spill back from human transmission, perpetuated by Aedes aegypti, into a sylvatic cycle maintained in wildlife and forest-living mosquitoes. In the Americas, Sabethes species are vectors of sylvatic yellow fever virus (YFV) and are therefore candidate vectors of a sylvatic ZIKV cycle. To test the potential of Sabethes cyaneus to transmit ZIKV, Sa. cyaneus and Ae. aegypti were fed on A129 mice one or two days post-infection (dpi) with a ZIKV isolate from Mexico. Sa. cyaneus were sampled at 3, 4, 5, 7, 14, and 21 days post-feeding (dpf) and Ae. aegypti were sampled at 14 and $21 \mathrm{dpf}$. ZIKV was quantified in mosquito bodies, legs, and saliva to measure infection, dissemination, and potential transmission, respectively. Of $69 \mathrm{Sa}$. cyaneus that fed, ZIKV was detected in only one, in all body compartments, at $21 \mathrm{dpf}$. In contrast, at $14 \mathrm{dpf} 100 \%$ of $20 \mathrm{Ae}$. aegypti that fed on mice at $2 \mathrm{dpi}$ were infected and $70 \%$ had virus in saliva. These data demonstrate that Sa. cyaneus is a competent vector for ZIKV, albeit much less competent than Ae. aegypti.
\end{abstract}

Keywords: Sabethes cyaneus; Zika virus; Aedes aegypti; sylvatic cycle; vector competence; Americas; spillback

\section{Introduction}

Mosquito-borne Zika virus (ZIKV; genus Flavivirus) originated in a sylvatic cycle of transmission between arboreal Aedes mosquitoes and wildlife, including non-human primates, in Africa [1,2]. Between its discovery in 1947 and 2006, the virus was detected in a limited range within the tropical belt of Africa and Asia, and human cases during this time were primarily attributable to spillover from the sylvatic cycle [1]. However, in 2007, an epidemic of ZIKV occurred on Yap island, where the virus was most likely transmitted by Ae. (Stegomyia) hensilii [3]. In 2013, ZIKV invaded French Polynesia 
and then the Americas, where it initiated explosive spread among humans via the urban vector Ae. (Stegomyia) aegypti $[1,2,4]$. At this time, the link between Zika virus infection of pregnant women and Zika congenital syndrome, particularly the manifestation of microcephaly, was first established [5].

The introduction of ZIKV to the New World raised concern that the virus would spill back into a sylvatic cycle in its new range [1,6]. We recently demonstrated, via mathematical modeling, that ZIKV does have high potential for such spillback in Brazil [6]. A sylvatic ZIKV cycle would preclude eradication of the virus from the Americas via human vaccination and undermine ZIKV control efforts [1,6]. The spillback of YFV, another flavivirus, which was introduced into the New World centuries ago via the slave trade, illustrates the potential for flaviviruses to establish novel sylvatic cycles and the risks such cycles pose [7,8]. YFV circulates between non-human primates and canopy-living mosquitoes, particularly Haemagogus and Sabethes, in the Americas [8]. Spillover from this cycle is currently driving an unprecedented outbreak of yellow fever among humans in Brazil [9].

One of the caveats of our modeling study was that more data was urgently needed on susceptibility of New World primates and sylvatic mosquitoes to ZIKV [6]. Subsequently, we and others have demonstrated that New World monkeys are susceptible to ZIKV in the laboratory [10-12] and that free-living monkeys are becoming infected with ZIKV in Brazil [9,13]. However, to our knowledge, the vector competence of sylvatic New World mosquitoes for ZIKV has not yet been tested. To help close this knowledge gap, we tested the vector competence of Sabethes cyaneus, which inhabits neotropical forests from Belize south to Argentina (http:/ / www.mosquitocatalog.org/taxon_descr. aspx?ID=15874) for ZIKV.

\section{Materials and Methods}

\subsection{Virus Strains and Cell Lines}

Ae. albopictus (C6/36) cells were maintained in minimum essential medium (MEM) supplemented with $10 \%$ heat-inactivated fetal bovine serum (FBS), $2 \mathrm{mM}$ L-glutamine, $2 \mathrm{mM}$ non-essential amino acids (all from Gibco, Life Technologies, Grand Island, NY, USA), and $0.05 \mathrm{mg} / \mathrm{mL}$ gentamycin (Invitrogen, Life Technologies, Grand Island, NY, USA) at $32{ }^{\circ} \mathrm{C}, 5 \% \mathrm{CO}_{2}$, and $85 \%$ relative humidity (RH). African green monkey kidney (Vero) cells (CCL-81) were maintained in DMEM supplemented with 5\% FBS and Penicillin/Streptomycin (P/S; 100 Units/mL and $100 \mu \mathrm{g} / \mathrm{mL}$ respectively) at $37{ }^{\circ} \mathrm{C}, 5 \% \mathrm{CO}_{2}$, and $85 \%$ RH. Zika virus (strain Mex-1-7 obtained from the University of Texas Medical Branch's World Reference Center for Emerging Viruses and Arboviruses) was used to infect mosquitoes and mice. ZIKV MEX 1-7 (Genbank accession. No. KX247632) was originally isolated from Ae, aegypti from Chiapas (Mexico) in 2015, and subsequently passaged on Vero (4x), C6/36 (1x), and Vero (3x) and C6/36 (2x) cells.

\subsection{Mosquito Strains}

Although the particular species Sa. cyaneus is not a known vector of arboviruses, it was chosen for this study because there is a stable colony available, and at least a subset of the individuals of this colony are willing to feed on mice. The Majé strain of Sa. cyaneus was isolated by Dr. Woodbridge Foster on Isla de Majé, Lago Bayano in eastern Panama in 1988 and maintained continuously at The Ohio State University until 2016, when a portion of the colony was transferred to New Mexico State University. Sa. cyaneus were maintained at $28^{\circ} \mathrm{C}$ and $80 \% \mathrm{RH}$ in BugDorm cages $(30 \times 30 \times 30 \mathrm{~cm}$, Bioquip, Rancho Dominguez, CA, USA) provisioned with branches that served as mating locations, artificial tree holes containing water for oviposition, and two separate Erlenmeyer flasks with a cotton ball wick, one each containing water or $20 \%$ sucrose. The mosquitoes were allowed to feed weekly on one investigator's (I.A. Hansen) hand for 15-30 min for blood meal (per approved NMSU IRB application 15308). Eggs were transferred from the artificial tree holes into rearing. Larvae were fed with dry cat food pellets (Special Kitty, Walmart, Bentonville, AR, USA) ad lib. See Supplementary Video 1 for a detailed protocol for maintenance of Sa. cyaneus. An Ae. aegypti strain from Salvador, 
Brazil at the F7 generation was used as a benchmark for vector competence; these were maintained as previously described [14]. Both species were reared in a common incubator at the University of Texas Medical Branch for the infection studies at $27{ }^{\circ} \mathrm{C} \pm 1{ }^{\circ} \mathrm{C}, 16: 8 \mathrm{~L}: \mathrm{D}, 80 \% \mathrm{RH}$ and maintained in this incubator after feeding on infected mice.

\subsection{Mouse Infections and Mosquito Feeding}

We have previously shown that ZIKV is more infectious to mosquitoes that imbibe the virus from a live, viremic host than from an artificial bloodmeal [14]. Thus we infected A129 mice lacking the interferon (IFN) alpha and beta-receptor with ZIKV as described in detail previously [14]. Briefly, three-week-old mice were injected intraperitoneally with $1 \times 10^{5} \mathrm{pfu} / \mathrm{mouse} \mathrm{ZIKV}$. To facilitate mosquito feeding, mice were anesthetized via intraperitoneal injection with $100 \mathrm{mg} / \mathrm{kg}$ ketamine and $10 \mathrm{mg} / \mathrm{kg}$ xylazine in a volume of $100 \mu \mathrm{L}$ Cartons of Sa. cyaneus or Ae. aegypti were allowed to feed on mice one day or two dpi for $30 \mathrm{~min}$, after which they were cold-anesthetized and engorged mosquitoes were separated and returned to normal maintenance conditions. Serum was collected from each infected mouse after mosquito feeding and the virus titer was determined using a focus-forming assay as previously described [14]. The titers of these samples were $5.38 \log _{10} \mathrm{pfu} / \mathrm{mL}$ at $1 \mathrm{dpi}$ and $6.83 \log _{10} \mathrm{pfu} / \mathrm{mL}$ at $2 \mathrm{dpi}$, respectively. All animal procedures and manipulations were approved by the UTMB Institutional Animal Care and Use Committee (IACUC) (protocol \#170851 approved 2 February 2018).

\subsection{Mosquito Incubation and Virus Quantification}

A subsample of 5 to $9 \mathrm{Sa}$. cyaneus was collected on $3,4,5,7$, and $14 \mathrm{dpf}$ from the batch of mosquitoes fed on the mice at $1 \mathrm{dpi}$ and $3,4,5,7,14$, and $21 \mathrm{dpf}$ from the batch of mosquitoes fed on the mice at $2 \mathrm{dpi}$. A subsample of 10 Ae. aegypti was collected on 14 and $21 \mathrm{dpf}$ from each of the batches of mosquitoes fed on mice 1 and 2 dpi. To collect saliva, individual mosquitoes were cold-anesthetized and legs were removed and retained in a microfuge tube containing a steel ball bearing and $500 \mu \mathrm{L}$ of homogenization media, consisting of $500 \mu \mathrm{L}$ of DMEM (Gibco, Grand Island, NY, USA) supplemented with $2 \%$ FBS, 1\% P/S (Gibco) and $2.5 \mu \mathrm{g} / \mathrm{mL}$ amphotericin B (Gibco). Mosquitoes were affixed to a glass slide using mineral oil and the proboscis was inserted into a sterile micropipette tip containing $8 \mu \mathrm{L}$ FBS and allowed to expectorate for $30 \mathrm{~min}$. The expectorate was then transferred into $100 \mu \mathrm{L}$ of homogenization media. Finally, the mosquito body was placed into a microtube containing $500 \mu \mathrm{L}$ homogenization media and a steel ball bearing. Bodies and legs were triturated for $5 \mathrm{~min}$ at $26 \mathrm{~Hz}$ in a TissueLyser II (Qiagen, Venio, The Netherlands) and clarified by centrifugation.

Virus titer was determined in each sample via plaque-forming unit assay on C6/36 cells using anti-ZIKV hyperimmune serum against ZIKV strain MR-766 at a 1:5000 dilution, and peroxidase-labeled goat anti-mouse secondary antibody (Kirkegaard and Perry Laboratories, Inc., Gaithersburg, MD, USA) at a 1:1000 dilution following previously described methods [15]. The units of resulting titers are given as $\log _{10} \mathrm{pfu} / \mathrm{sample}$ per Hanley et al. [16]. All statistical analysis was conducted using JMP Pro 13 (SAS Institute Inc., Cary, NC, USA).

\section{Results}

Feeding rates for Sa. cyaneus were low, with $21 \%$ feeding on the mouse at $1 \mathrm{dpi}$ and $28 \%$ feeding on the mouse at $2 \mathrm{dpi}$; in contrast, more than $85 \%$ of Ae. aegypti fed on the mice on each day. Of 69 engorged Sa. cyaneus, ZIKV was detected in only one individual (Table 1), albeit in all body compartments sampled (body, legs, and saliva). This mosquito had fed on a mouse at day 2 dpi; titers increased in the mice by approximately tenfold between day 1 and day $2 \mathrm{pi}\left(5.38 \log _{10} \mathrm{pfu} / \mathrm{mL}\right.$ to $6.83 \log _{10} \mathrm{pfu} / \mathrm{mL}$ ). Moreover the one infected Sa. cyaneus had been allowed to incubate for 21 days, the maximum time period utilized in this study. The small sample size of infected $\mathrm{Sa}$. cyaneus precluded statistical analysis of the effects of the experimental manipulations (mouse dpi or mosquito dpf) on infection or a statistical comparison with Ae. aegypti. 
Table 1. Infection, dissemination, and potential transmission of ZIKV in Sabethes cyaneus fed on infected A129 mice.

\begin{tabular}{ccccccc}
\hline $\begin{array}{c}\text { Mosquito Day } \\
\text { Post-Feeding }\end{array}$ & $\begin{array}{c}\text { Mouse Day } \\
\text { Post-Infection }\end{array}$ & $\begin{array}{c}\text { ZIKV Titer } \\
\left(\log _{\mathbf{1 0}} \mathbf{p f u} / \mathbf{m L}\right)\end{array}$ & N & $\begin{array}{c}\text { No. (\%) } \\
\text { Infection }\end{array}$ & $\begin{array}{c}\text { No. (\%) } \\
\text { Dissemination }\end{array}$ & $\begin{array}{c}\text { No. (\%) } \\
\text { Transmission }\end{array}$ \\
\hline 3 & 1 & 5.38 & 5 & 0 & 0 & 0 \\
4 & 1 & 5.38 & 5 & 0 & 0 & 0 \\
5 & 1 & 5.38 & 5 & 0 & 0 & 0 \\
7 & 1 & 5.38 & 5 & 0 & 0 & 0 \\
14 & 1 & 5.38 & 5 & 0 & 0 & 0 \\
3 & 2 & 6.83 & 7 & 0 & 0 & 0 \\
4 & 2 & 6.83 & 7 & 0 & 0 & 0 \\
5 & 2 & 6.83 & 7 & 0 & 0 & 0 \\
7 & 2 & 6.83 & 7 & 0 & 0 & 0 \\
14 & 2 & 6.83 & 7 & 0 & 0 & 0 \\
21 & 2 & 6.83 & 9 & $1(11.1)$ & $1(11.1)$ & $1(11.1)$ \\
\hline
\end{tabular}

In contrast, Ae. aegypti showed high levels of ZIKV infection, dissemination, and transmission (Table 2). Among mosquitoes fed on the mouse at day 2 pi, 100\% showed infection and dissemination by day 14 and $70 \%$ showed potential transmission. A nominal logistic analysis was used to test the effects of mouse dpi, mosquito dpf, and their interaction on the percent Ae. aegypti infected, disseminated or transmitting. The interaction between mouse dpi and mosquito dpf, as well as mosquito dpf independently, did not have a significant effect on any of these outcomes $(p>0.05$ for all comparisons). Mouse dpi, which reflects virus titer, did have a significant effect on percent mosquitoes infected ( $\mathrm{DF}=1$, chi squared $=13.68, p=0.0002)$, the percent mosquitoes in which ZIKV disseminated $(\mathrm{DF}=1$, chi squared $=21.02, p<0.0001)$, and the percent of mosquitoes with potential transmission from saliva ( $\mathrm{DF}=1$, chi squared $=13.68, p=0.0002)$, with higher percentages of ZIKV positive bodies, legs, and saliva among mosquitoes fed on the mouse at $2 \mathrm{dpi}$.

Table 2. Infection, dissemination, and transmission of ZIKV in Aedes aegypti.

\begin{tabular}{ccccccc}
\hline $\begin{array}{c}\text { Mosquito Day } \\
\text { Post-Feeding }\end{array}$ & $\begin{array}{c}\text { Mouse Day } \\
\text { Post-Infection }\end{array}$ & $\begin{array}{c}\text { ZIKV Titer } \\
\left(\mathbf{l o g}_{\mathbf{1 0}} \mathbf{p f u} / \mathbf{m L}\right)\end{array}$ & $\mathbf{N}$ & $\begin{array}{c}\text { No. (\%) } \\
\text { Infection }\end{array}$ & $\begin{array}{c}\text { No. (\%) } \\
\text { Dissemination }\end{array}$ & $\begin{array}{c}\text { No. (\%) } \\
\text { Transmission }\end{array}$ \\
\hline 14 & 1 & 5.38 & 10 & $3(30)$ & $1(10)$ & $0(0)$ \\
21 & 1 & 5.38 & 10 & $4(40)$ & $2(20)$ & $2(20)$ \\
14 & 2 & 6.83 & 10 & $10(100)$ & $10(100)$ & $7(70)$ \\
21 & 2 & 6.83 & 10 & $10(100)$ & $10(100)$ & $7(70)$ \\
\hline
\end{tabular}

The titer of ZIKV in the body and legs of the single infected Sa. cyaneus fell squarely within the range of ZIKV titers in the bodies and legs of infected Ae. aegypti (Table 3). However ZIKV titer in the saliva of Sa. cyaneus was almost two orders of magnitude lower than the ZIKV titer in the saliva of Ae. aegypti (Table 3).

Table 3. ZIKV titer in infected tissues from Sabethes cyaneus and Ae. aegypti.

\begin{tabular}{|c|c|c|c|c|c|}
\hline Species & $\begin{array}{l}\text { Mosquito Day } \\
\text { Post Feeding }\end{array}$ & $\begin{array}{l}\text { Mouse Day } \\
\text { Post Infection }\end{array}$ & $\begin{array}{c}\text { Mean Body Titer * } \\
\left(\log _{10} \mathrm{pfu} / \mathrm{mL}\right) \pm \\
\text { 1SE (N) }\end{array}$ & $\begin{array}{c}\text { Mean Legs Titer * } \\
\left(\log _{10} \mathrm{pfu} / \mathrm{mL}\right) \pm \\
\text { 1SE (N) }\end{array}$ & $\begin{array}{c}\text { Mean Saliva Titer * } \\
\left(\log _{10} \mathrm{pfu} / \mathrm{mL}\right) \pm \\
\text { 1SE (N) }\end{array}$ \\
\hline $\begin{array}{l}\text { Sabethes } \\
\text { cyaneus }\end{array}$ & 21 & 2 & $5.4(1)$ & $4.4(1)$ & $1.1(1)$ \\
\hline $\begin{array}{l}\text { Aedes } \\
\text { aegypti }\end{array}$ & $\begin{array}{l}14 \\
21 \\
14 \\
21\end{array}$ & $\begin{array}{l}1 \\
1 \\
2 \\
2\end{array}$ & $\begin{array}{c}4.5 \pm 0.2(3) \\
5.1 \pm 0.2(4) \\
5.2 \pm 0.2(10) \\
5.7 \pm 0.1(10)\end{array}$ & $\begin{array}{c}3.2(1) \\
4.4 \pm 0.4(2) \\
4.4 \pm 0.4(10) \\
4.7 \pm 0.3(10)\end{array}$ & $\begin{array}{c}\text { NA (0) } \\
2.8 \pm 1.0(2) \\
2.8 \pm 0.3(7) \\
2.9 \pm 0.5(7)\end{array}$ \\
\hline
\end{tabular}

${ }^{*}$ Mean values are calculated from samples with detectable virus. 


\section{Discussion}

Here we have shown for the first time that $\mathrm{Sa}$. cyaneus is a competent vector for a New World strain of ZIKV, although its competence is orders of magnitude lower than that of Ae. aegypti. The minimum extrinsic incubation period (EIP) of ZIKV in Sa. cyaneus measured in this study was between 15 and 21 days, substantially longer than the EIP of ZIKV in Ae. aegypti measured in this and other studies [2,14]. Although it must be considered preliminary due to the low number of Sa. cyaneus infected, this estimate of EIP is consistent with the long EIP of YFV in forest-living New World mosquitoes. Studies conducted in the 1930s and 1940s have shown that the minimum EIP required for various Haemogogus species to transmit YFV to monkeys was 13 days, much longer than for Ae. aegypti [17,18]. These same studies also showed that the number of mosquitoes capable of transmission increased dramatically between 13 and 21 days post-feeding. Similarly, Couto-Lima et al. [19] reported a minimum YFV EIP of 14 days in H. leucolaenas and S. albiprivus. Galindo et al. [20] found that the EIP of YFV in H. mesodentatus gorgasi, $H$. mesodentatus mesodentatus, H. equinus and S. chloropterus was $\leq 26-27$ days, but 26 days was the earliest time post-feeding tested. Our data are also in line with studies of the competence of sylvatic Aedes species in Africa for ZIKV. Diagne et al. [21] fed four Aedes species on artificial bloodmeals containing six strains of ZIKV and monitored virus presence in the body, legs, and saliva at 5, 10, and 15 dpf. They found that only two species, Ae. (Fredwardsius) vittatus and Ae. (Stegomyia) luteocephalus, expectorated detectable virus, and this occurred only at $15 \mathrm{dpf}$.

Several caveats to the current study must be acknowledged. First, the Sa. cyaneus utilized have been maintained in a colony for decades, whereas the Ae. aegypti were only seven generations removed from wild type. Maintenance in a colony can impact vector competence for flaviviruses [22]. However, studies that utilized field collected Haemagogus nonetheless showed a long EIP for YFV [17-19], suggesting that our observations may reflect the actual dynamics of ZIKV in Sa. cyaneus. We have efforts ongoing to collect Sabethes and Haemagogus mosquitoes in the forest canopies in and around Manaus, Brazil in order to establish collections of field-caught and low-generation colony mosquitoes for vector competence testing. Second, a relatively small number of Sa. cyaneus fed on infected mice. This species is extremely difficult to maintain in colony and does not readily feed on mice; even under our tailored feeding protocol, a maximum $28 \%$ feeding efficiency was observed. Third, we utilized only one strain of ZIKV. We and others have previously shown that ZIKV strains differ in their ability to infect, disseminate and be transmitted in saliva in Ae. aegypti [14,23] and Ae. (Stegomyia) albopictus [24], and it therefore seems likely that strains may also vary in their ability to infect $S a$. cyaneus. Nonetheless, we do know that the ZIKV strain used in the current study is quite infectious for both Ae. aegypti (this study) and Ae. albopictus [24]. Finally, the ZIKV titers achieved in A129 mice were several orders of magnitude higher than those reported for humans, i.e., [25-27] or New World non-human primates [10-12], although these comparisons are indirect as most of the human and non-human primate studies quantified viremia via measurement of the viral genome rather than infectious virus. Generally, the percentage of mosquitoes infected is positively correlated with arbovirus titer in the bloodmeal [28].

Despite these limitations, the current study offers the first view of vector competence and EIP of any New World sylvatic mosquito vector for ZIKV. EIP is a critical parameter for models of arbovirus transmission [29], Although we were not able to measure the $\mathrm{EIP}_{50}$ of ZIKV in Sa. cyaneus due it its low overall competence [30], nonetheless, the data generated here can be used to refine models of ZIKV spillback [6]. While Sabethes cyaneus has not itself been implicated as a vector of any arbovirus, other Sabethes species have been shown to carry the flaviviruses YFV [31-35], dengue virus [36], and Ilheus virus [37] as well as the rhabdovirus Xiburema virus [38]. Sabethes species are highly abundant in the forest canopy [39-42], occur in forested areas of large cities [43-45], have long lifespans in nature that exceed the 21 day EIP measured here [46], and have been collected via human land catch [47,48]. Together, these traits suggest that species in this genus have high potential act as bridge vectors [49] for spillback from humans to wildlife. 
Supplementary Materials: Supplementary materials can be found at www.mdpi.com/1999-4915/10/8/434/s1.

Author Contributions: Conceptualization, I.A.H. and K.A.H.; Data curation, A.K.K. and S.R.A.; Formal analysis, K.A.H.; Funding acquisition, N.V., S.C.W. and K.A.H.; Investigation, A.K.K., S.R.A., J.A.P. and R.Y.; Methodology, S.R.A., I.A.H. and K.A.H.; Project administration, K.A.H.; Resources, S.R.A., J.A.P. and I.A.H.; Supervision, N.V., S.C.W. and I.A.H.; Validation, K.A.H.; Visualization, I.A.H.; Writing-Original draft, K.A.H.; Writing-Review \& editing, A.K.K., S.R.A., J.A.P., R.Y., N.V., S.C.W., I.A.H. and K.A.H.

Funding: This research was funded by NIH 1R15AI113628-01, R24AI120942, and NIH ICIDR 1U01AI115577-01; the concept for this study was shaped by the NSF-funded Research Coordination Network Infectious Disease Evolution Across Scales.

Acknowledgments: We offer warm thanks to Woodbridge Foster for providing us with Sabethes cyaneus as well as information on the history of the colony, to Stacy Rodriguez, NMSU, for assistance with mosquito colony maintenance, and to Julia Vulcan, NMSU, for production of the rearing video.

Conflicts of Interest: The authors declare no conflict of interest.

\section{References}

1. Vasilakis, N.; Weaver, S.C. Flavivirus transmission focusing on Zika. Curr. Opin. Virol. 2017, 22, 30-35. [CrossRef] [PubMed]

2. Boyer, S.; Calvez, E.; Chouin-Carneiro, T.; Diallo, D.; Failloux, A.B. An overview of mosquito vectors of Zika virus. Microbes. Infect. 2018. [CrossRef] [PubMed]

3. Duffy, M.R.; Chen, T.H.; Hancock, W.T.; Powers, A.M.; Kool, J.L.; Lanciotti, R.S.; Pretrick, M.; Marfel, M.; Holzbauer, S.; Dubray, C.; et al. Zika virus outbreak on Yap Island, Federated States of Micronesia. N. Engl. J. Med. 2009, 360, 2536-2543. [CrossRef] [PubMed]

4. Guerbois, M.; Fernandez-Salas, I.; Azar, S.R.; Danis-Lozano, R.; Alpuche-Aranda, C.M.; Leal, G.; Garcia-Malo, I.R.; Diaz-Gonzalez, E.E.; Casas-Martinez, M.; Rossi, S.L.; et al. Outbreak of Zika Virus Infection, Chiapas State, Mexico, 2015, and first confirmed transmission by Aedes aegypti mosquitoes in the Americas. J. Infect. Dis. 2016, 214, 1349-1356. [CrossRef] [PubMed]

5. Aliota, M.T.; Bassit, L.; Bradrick, S.S.; Cox, B.; Garcia-Blanco, M.A.; Gavegnano, C.; Friedrich, T.C.; Golos, T.G.; Griffin, D.E.; Haddow, A.D.; et al. Zika in the Americas, year 2: What have we learned? What gaps remain? A report from the Global Virus Network. Antivir. Res. 2017, 144, 223-246. [CrossRef] [PubMed]

6. Althouse, B.M.; Vasilakis, N.; Sall, A.A.; Diallo, M.; Weaver, S.C.; Hanley, K.A. Potential for Zika Virus to establish a sylvatic transmission cycle in the Americas. PLoS Negl. Trop. Dis. 2016, 10, e0005055. [CrossRef] [PubMed]

7. Bryant, J.E.; Holmes, E.C.; Barrett, A.D. Out of Africa: A molecular perspective on the introduction of yellow fever virus into the Americas. PLoS Pathog. 2007, 3, e75. [CrossRef] [PubMed]

8. Hanley, K.A.; Monath, T.P.; Weaver, S.C.; Rossi, S.L.; Richman, R.L.; Vasilakis, N. Fever versus fever: The role of host and vector susceptibility and interspecific competition in shaping the current and future distributions of the sylvatic cycles of dengue virus and yellow fever virus. Infect. Genet. Evol. J. Mol. Epidemiol. Evol. Genet. Infect. Dis. 2013, 19, 292-311. [CrossRef] [PubMed]

9. Moreira-Soto, A.; Torres, M.C.; Lima de Mendonca, M.C.; Mares-Guia, M.A.; Dos Santos Rodrigues, C.D.; Fabri, A.A.; Dos Santos, C.C.; Machado Araujo, E.S.; Fischer, C.; Ribeiro Nogueira, R.M.; et al. Evidence for multiple sylvatic transmission cycles during the 2016-2017 yellow fever virus outbreak, Brazil. Clin. Microbiol. Infect. 2018. [CrossRef] [PubMed]

10. Vanchiere, J.A.; Ruiz, J.C.; Brady, A.G.; Kuehl, T.J.; Williams, L.E.; Baze, W.B.; Wilkerson, G.K.; Nehete, P.N.; McClure, G.B.; Rogers, D.L.; et al. Experimental Zika Virus Infection of Neotropical Primates. Am. J. Trop. Med. Hyg. 2018, 98, 173-177. [CrossRef] [PubMed]

11. Seferovic, M.; Martin, C.S.; Tardif, S.D.; Rutherford, J.; Castro, E.C.C.; Li, T.; Hodara, V.L.; Parodi, L.M.; Giavedoni, L.; Layne-Colon, D.; et al. Experimental Zika virus infection in the pregnant common marmoset induces spontaneous fetal loss and neurodevelopmental abnormalities. Sci. Rep. 2018, 8, 6851. [CrossRef] [PubMed]

12. Chiu, C.Y.; Sanchez-San Martin, C.; Bouquet, J.; Li, T.; Yagi, S.; Tamhankar, M.; Hodara, V.L.; Parodi, L.M.; Somasekar, S.; Yu, G.; et al. Experimental Zika virus inoculation in a New World monkey model reproduces key features of the human infection. Sci. Rep. 2017, 7, 17126. [CrossRef] [PubMed] 
13. Terzian, A.C.B.; Zini, N.; Rocha, R.F.; Sacchetto, L.; Sarto, J.L.; Coutinho, F.; Rayra, J.; da Silva, R.A.; Dias, A.C.F.; Fernandes, N.C.C.A.; et al. Detection of Zika virus in neotropical non-human primates from Brazil: Evidence of natural infection. Sci. Rep. 2018. in revision.

14. Roundy, C.M.; Azar, S.R.; Rossi, S.L.; Huang, J.H.; Leal, G.; Yun, R.; Fernandez-Salas, I.; Vitek, C.J.; Paploski, I.A.; Kitron, U.; et al. Variation in Aedes aegypti mosquito competence for Zika virus transmission. Emerg. Infect. Dis. 2017, 23, 625-632. [CrossRef] [PubMed]

15. Andrade, C.C.; Young, K.I.; Johnson, W.L.; Villa, M.E.; Buraczyk, C.A.; Messer, W.B.; Hanley, K.A. Rise and fall of vector infectivity during sequential strain displacements by mosquito-borne dengue virus. J. Evol. Biol. 2016, 29, 2205-2218. [CrossRef] [PubMed]

16. Hanley, K.A.; Nelson, J.T.; Schirtzinger, E.E.; Whitehead, S.S.; Hanson, C.T. Superior infectivity for mosquito vectors contributes to competitive displacement among strains of dengue virus. BMC Ecol. 2008, 8, 1. [CrossRef] [PubMed]

17. Antunes, P.C.A.; Whitman, L. Studies on the capacity of mosquitoes of the genus Haemagogus to transmit yellow fever. Am. J. Trop. Med. Hyg. 1937, 17, 825-831. [CrossRef]

18. Bates, M.; Roca-Garcia, M. Laboratory studies of the Saimiri-Haemagogus cycle of jungle yellow fever. Am. J. Trop. Med. Hyg. 1945, 25, 203-216. [CrossRef]

19. Couto-Lima, D.; Madec, Y.; Bersot, M.I.; Campos, S.S.; Motta, M.A.; Santos, F.B.D.; Vazeille, M.; Vasconcelos, P.; Lourenco-de-Oliveira, R.; Failloux, A.B. Potential risk of re-emergence of urban transmission of Yellow Fever virus in Brazil facilitated by competent Aedes populations. Sci. Rep. 2017, 7, 4848. [CrossRef] [PubMed]

20. Galindo, P.; De Rodaniche, E.; Trapido, H. Experimental transmission of yellow fever by Central American species of Haemagogus and Sabethes chloropterus. Am. J. Trop. Med. Hyg. 1956, 5, 1022-1031. [CrossRef]

21. Diagne, C.T.; Diallo, D.; Faye, O.; Ba, Y.; Faye, O.; Gaye, A.; Dia, I.; Faye, O.; Weaver, S.C.; Sall, A.A.; et al. Potential of selected Senegalese Aedes spp. mosquitoes (Diptera: Culicidae) to transmit Zika virus. BMC Infect. Dis. 2015, 15, 492. [CrossRef] [PubMed]

22. Lorenz, L.; Beaty, B.J.; Aitken, T.H.; Wallis, G.P.; Tabachnick, W.J. The effect of colonization upon Aedes aegypti susceptibility to oral infection with yellow fever virus. Am. J. Trop. Med. Hyg. 1984, 33, 690-694. [CrossRef] [PubMed]

23. Weger-Lucarelli, J.; Ruckert, C.; Chotiwan, N.; Nguyen, C.; Garcia Luna, S.M.; Fauver, J.R.; Foy, B.D.; Perera, R.; Black, W.C.; Kading, R.C.; et al. Vector competence of American mosquitoes for three strains of Zika virus. PLoS Negl. Trop. Dis. 2016, 10, e0005101. [CrossRef] [PubMed]

24. Azar, S.R.; Roundy, C.M.; Rossi, S.L.; Huang, J.H.; Leal, G.; Yun, R.; Fernandez-Salas, I.; Vitek, C.J.; Paploski, I.A.D.; Stark, P.M.; et al. Differential vector competency of Aedes albopictus populations from the Americas for Zika virus. Am. J. Trop. Med. Hyg. 2017, 97, 330-339. [CrossRef] [PubMed]

25. Mansuy, J.M.; Mengelle, C.; Pasquier, C.; Chapuy-Regaud, S.; Delobel, P.; Martin-Blondel, G.; Izopet, J. Zika virus infection and prolonged viremia in whole-blood specimens. Emerg. Infect. Dis. 2017, 23, 863-865. [CrossRef] [PubMed]

26. Terzian, A.C.B.; Schanoski, A.S.; Mota, M.T.O.; da Silva, R.A.; Estofolete, C.F.; Colombo, T.E.; Rahal, P.; Hanley, K.A.; Vasilakis, N.; Kalil, J.; et al. Viral load and cytokine response profile does not support antibody-dependent enhancement in dengue-primed Zika virus-infected patients. Clin. Infect. Dis. 2017, 65, 1260-1265. [CrossRef] [PubMed]

27. Waggoner, J.J.; Gresh, L.; Vargas, M.J.; Ballesteros, G.; Tellez, Y.; Soda, K.J.; Sahoo, M.K.; Nunez, A.; Balmaseda, A.; Harris, E.; et al. Viremia and clinical presentation in Nicaraguan patients infected with Zika virus, chikungunya virus, and dengue virus. Clin. Infect. Dis. 2016, 63, 1584-1590. [CrossRef] [PubMed]

28. Althouse, B.M.; Hanley, K.A. The tortoise or the hare? Impacts of within-host dynamics on transmission success of arthropod-borne viruses. Philos. Trans. R. Soc. Lond. B Biol. Sci. 2015, 370, 20140299. [CrossRef] [PubMed]

29. Christofferson, R.C.; Mores, C.N. Estimating the magnitude and direction of altered arbovirus transmission due to viral phenotype. PLoS ONE 2011, 6, e16298. [CrossRef] [PubMed]

30. Christofferson, R.C.; Mores, C.N.; Wearing, H.J. Bridging the gap between experimental data and model parameterization for chikungunya virus transmission predictions. J. Infect. Dis. 2016, 214, S466-S470. [CrossRef] [PubMed] 
31. Goenaga, S.; Fabbri, C.; Duenas, J.C.; Gardenal, C.N.; Rossi, G.C.; Calderon, G.; Morales, M.A.; Garcia, J.B.; Enria, D.A.; Levis, S. Isolation of yellow fever virus from mosquitoes in Misiones province, Argentina. Vector Borne Zoonotic Dis. 2012, 12, 986-993. [CrossRef] [PubMed]

32. Vasconcelos, P.F.; Rodrigues, S.G.; Degallier, N.; Moraes, M.A.; da Rosa, J.F.; da Rosa, E.S.; Mondet, B.; Barros, V.L.; da Rosa, A.P. An epidemic of sylvatic yellow fever in the southeast region of Maranhao State, Brazil, 1993-1994: Epidemiologic and entomologic findings. Am. J. Trop. Med. Hyg. 1997, 57, 132-137. [CrossRef] [PubMed]

33. Rawlins, S.C.; Hull, B.; Chadee, D.D.; Martinez, R.; LeMaitre, A.; James, F.; Webb, L. Sylvatic yellow fever activity in Trinidad, 1988-1989. Trans. R. Soc. Trop. Med. Hyg. 1990, 84, 142-143. [CrossRef]

34. De Rodaniche, E.; Galindo, P. Isolation of yellow fever virus from Haemagogus mesodentatus, H. equinus and Sabethes chloropterus captured in Guatemala in 1956. Am. J. Trop. Med. Hyg. 1957, 6, 232-237. [PubMed]

35. De Rodaniche, E.; Galindo, P.; Johnson, C.M. Isolation of yellow fever virus from Haemagogus lucifer, H. equinus, H. spegazzinii falco, Sabethes chloropterus and Anopheles neivai captured in Panama in the fall of 1956. Am. J. Trop. Med. Hyg. 1957, 6, 681-685. [PubMed]

36. Serra, O.P.; Cardoso, B.F.; Ribeiro, A.L.; Santos, F.A.; Slhessarenko, R.D. Mayaro virus and dengue virus 1 and 4 natural infection in culicids from Cuiaba, state of Mato Grosso, Brazil. Mem. Inst. Oswaldo Cruz 2016, 111, 20-29. [CrossRef] [PubMed]

37. De Rodaniche, E.; Galindo, P. Isolation of Ilheus virus from Sabethes chloropterus captured in Guatemala in 1956. Am. J. Trop. Med. Hyg. 1957, 6, 686-687. [CrossRef] [PubMed]

38. Wanzeller, A.L.; Martins, L.C.; Diniz Junior, J.A.; de Almeida Medeiros, D.B.; Cardoso, J.F.; da Silva, D.E.; de Oliveira, L.F.; de Vasconcelos, J.M.; Nunes, M.R.; Vianez Junior, J.L.; et al. Xiburema virus, a hitherto undescribed virus within the family Rhabdoviridae isolated in the Brazilian Amazon region. Genome Announc. 2014, 2, e00454-14. [CrossRef] [PubMed]

39. Tubaki, R.M.; Menezes, R.M.; Vesgueiro, F.T.; Cardoso, R.P., Jr. Observations on Haemagogus janthinomys Dyar (Diptera: Culicidae) and other mosquito populations within tree holes in a gallery forest in the northwestern region of Sao Paulo state, Brazil. Neotrop. Entomol. 2010, 39, 664-670. [CrossRef] [PubMed]

40. Silva Jdos, S.; Pacheco, J.B.; Alencar, J.; Guimaraes, A.E. Biodiversity and influence of climatic factors on mosquitoes (Diptera: Culicidae) around the Peixe Angical hydroelectric scheme in the state of Tocantins, Brazil. Mem. Inst. Oswaldo Cruz 2010, 105, 155-162. [CrossRef] [PubMed]

41. Pinto, C.S.; Confalonieri, U.E.; Mascarenhas, B.M. Ecology of Haemagogus sp. and Sabethes sp. (Diptera: Culicidae) in relation to the microclimates of the Caxiuana National Forest, Para, Brazil. Mem. Inst. Oswaldo Cruz 2009, 104, 592-598. [CrossRef] [PubMed]

42. Chaverri, L.G.; Dillenbeck, C.; Lewis, D.; Rivera, C.; Romero, L.M.; Chaves, L.F. Mosquito species (Diptera: Culicidae) diversity from ovitraps in a Mesoamerican tropical rainforest. J. Med. Entomol. 2018, 55, 646-653. [CrossRef] [PubMed]

43. Mangudo, C.; Aparicio, J.P.; Rossi, G.C.; Gleiser, R.M. Tree hole mosquito species composition and relative abundances differ between urban and adjacent forest habitats in northwestern Argentina. Bull. Entomol. Res. 2018, 108, 203-212. [CrossRef] [PubMed]

44. Camargo-Neves, V.L.; Poletto, D.W.; Rodas, L.A.; Pachioli, M.L.; Cardoso, R.P.; Scandar, S.A.; Sampaio, S.M.; Koyanagui, P.H.; Botti, M.V.; Mucci, L.F.; et al. Entomological investigation of a sylvatic yellow fever area in Sao Paulo State, Brazil. Cad. Saude Publ. 2005, 21, 1278-1286. [CrossRef]

45. Mucci, L.F.; Medeiros-Sousa, A.R.; Ceretti-Junior, W.; Fernandes, A.; Camargo, A.A.; Evangelista, E.; de Oliveira Christe, R.; Montes, J.; Teixeira, R.S.; Marrelli, M.T. Haemagogus leucocelaenus and other mosquitoes potentially associated with sylvatic yellow fever In Cantareira State Park In the Sao Paulo metropolitan area, Brazil. J. Am. Mosq. Control. Assoc. 2016, 32, 329-332. [CrossRef] [PubMed]

46. Degallier, N.; Sa Filho, G.C.; Monteiro, H.A.; Castro, F.C.; Da Silva, O.V.; Brandao, R.C.; Moyses, M.; Da Rosa, A.P. Release-recapture experiments with canopy mosquitoes in the genera Haemagogus and Sabethes (Diptera: Culicidae) in Brazilian Amazonia. J. Med. Entomol. 1998, 35, 931-936. [CrossRef] [PubMed]

47. Chadee, D.D. Seasonal abundance and diel landing periodicity of Sabethes chloropterus (Diptera: Culicidae) in Trinidad, West Indies. J. Med. Entomol. 1990, 27, 1041-1044. [CrossRef] [PubMed] 
48. Ribeiro, A.L.; Miyazaki, R.D.; Silva, M.; Zeilhofer, P. Spatial and temporal abundance of three sylvatic yellow fever vectors in the influence area of the Manso hydroelectric power plant, Mato Grosso, Brazil. J. Med. Entomol. 2012, 49, 223-226. [CrossRef] [PubMed]

49. Weaver, S.C. Host range, amplification and arboviral disease emergence. In Infectious Diseases From Nature: Mechanisms of Viral Emergence and Persistence; Springer: Vienna, Austria, 2005; pp. 33-44.

(C) 2018 by the authors. Licensee MDPI, Basel, Switzerland. This article is an open access article distributed under the terms and conditions of the Creative Commons Attribution (CC BY) license (http:/ / creativecommons.org/licenses/by/4.0/). 